\title{
Deoxyribonucleic Acid Similarities among Pseudomonas Species
}

\author{
JOHN L. JOHNSON ${ }^{1 *}$ AND NORBERTO J. PALLERONI ${ }^{2}$ \\ Department of Anaerobic Microbiology, Virginia Polytechnic Institute and State University, Blacksburg, Virginia 24061, ${ }^{1}$ \\ and Department of Microbiology, New York University Medical School, New York, New York 10016 ${ }^{2}$
}

\begin{abstract}
Deoxyribonucleic acid similarity experiments in which the S1 nuclease methodology was used were performed on strains of Pseudomonas species, including some that had not been previously subjected to similarity measurements. The results obtained with this technique confirmed and expanded previous observations on the low levels of deoxyribonucleic acid similarity among species of the genus as determined by membrane competition experiments. A general discussion of the results and nomenclatural status of some of the species is included.
\end{abstract}

\begin{abstract}
The genus Pseudomonas has been subdivided into five groups on the basis of ribosomal ribonucleic acid (rRNA)deoxyribonucleic acid (DNA) hybridization experiments (23, $24,27)$. This classification has received ample confirmation from work done in various laboratories in which a number of different experimental approaches have been used. In the years since it was first proposed, no significant changes have been required, with the exception of assignment of organisms to some of the groups of some Pseudomonas species that were not included in the original studies. Thus, in the recent rRNA-DNA hybridization study of Byng et al. (3), Pseudomonas panici, Pseudomonas synxantha, Pseudomonas angulata, and Pseudomonas fragi were found to belong to group I; Pseudomonas pyrrocinia and Pseudomonas andropogonis were found to belong to group II; and Pseudomonas geniculata was found to belong to group $\mathrm{V}$. In addition, Alcaligenes paradoxus was found to be related to organisms belonging to group II, and Alcaligenes eutrophus was found to be related to group III organisms.

The homogeneity within each Pseudomonas rRNA similarity cluster is very high, with most species having nearly $100 \%$ rRNA similarity $(3,27)$, although the levels of DNA similarity between species within each rRNA cluster are low (25). In contrast, we have not always found this clear clustering among groups of anaerobic bacteria (16-18). In order to confirm this rather interesting observation on the Pseudomonas groups and to extend DNA similarity measurements between additional species of the genus, the experiments described here were performed. In addition, some of the species were not included on the 1980 Approved Lists of Bacterial Names (33), and others appear to be synonyms. Nomenclatural proposals concerning some of these organisms are included below.
\end{abstract}

\section{MATERIALS AND METHODS}

Bacterial strains. The organisms used in this study were the same as those used in a previous rRNA similarity study (3). All were obtained from the American Type Culture Collection, Rockville, Md.

DNA preparation. The organisms were grown in a medium containing 1\% tryptone (BBL Microbiology Systems, Cockeysville, Md.), $0.5 \%$ yeast extract (Difco Laboratories, Detroit, Mich.), and $0.5 \%$ glucose. Erlenmeyer flasks (volume, 2 liters) containing $500 \mathrm{ml}$ of medium were inoculated with $5-\mathrm{ml}$ portions of broth cultures and shaken overnight at $250 \mathrm{rpm}$ on a rotary shaker at $30^{\circ} \mathrm{C}$. The harvested

\footnotetext{
* Corresponding author.
}

cells were suspended in a $0.15 \mathrm{M} \mathrm{NaCl}-0.01 \mathrm{M}$ ethylenediaminetetraacetic acid salt solution ( $\mathrm{pH} \mathrm{8.0),} \mathrm{and} \mathrm{DNA} \mathrm{was}$ isolated by the method of Marmur (22). The DNA preparations were dissolved in $0.1 \times \mathrm{SCC}(1 \times \mathrm{SCC}$ is $0.15 \mathrm{M} \mathrm{NaCl}$ plus $0.15 \mathrm{M}$ sodium citrate, $\mathrm{pH} 7.0$ ) and stored at $-20^{\circ} \mathrm{C}$. The DNA preparations were fragmented and denatured by two passages through a French pressure cell at $16,000 \mathrm{lb} / \mathrm{in}^{2}$, followed by heating in a boiling water bath for $5 \mathrm{~min}$. The concentrations were adjusted to $0.4 \mathrm{mg} / \mathrm{ml}$, and the preparations were stored at $-20^{\circ} \mathrm{C}$.

Preparation of labeled nucleic acids. Samples of the fragmented denatured DNA were labeled with ${ }^{125}$ I by using a variation of the thallium chloride method $(32,36)$.

DNA similarity methods. DNA similarity values were determined by using an S1 procedure, as described previously (15). The reassociation reaction mixtures contained 10 $\mu l$ of denatured labeled DNA $(0.01$ to $0.03 \mu \mathrm{g}), 50 \mu \mathrm{l}$ of denatured unlabeled DNA $(20 \mu \mathrm{g}), 25 \mu \mathrm{l}$ of a salt solution consisting of $5.28 \mathrm{M} \mathrm{NaCl}$ and $1 \mathrm{mM}$ HEPES [4-(2-hydroxyethyl)-1-piperazine-ethanesulfonic acid] $(\mathrm{pH} \mathrm{7.0)}$, and $25 \mu \mathrm{l}$ of deionized formamide. For measuring background reassociation and the S1-resistant material in the labeled DNA preparations, the denatured unlabeled DNA was replaced with $50 \mu \mathrm{l}(20 \mu \mathrm{g})$ of sheared native salmon sperm DNA. The reassociation vials were incubated at $63^{\circ} \mathrm{C}\left(25^{\circ} \mathrm{C}\right.$ below the thermal melting points of native reference DNAs in this buffer) for $20 \mathrm{~h}$. The $\mathrm{S} 1$ nuclease-resistant fragments from each vial were coprecipitated with $60 \mu \mathrm{g}$ of fragmented salmon sperm DNA, collected on type GF/F glass fiber filters (Whatman, Ltd., Kent, England), and counted with a gamma counter.

\section{RESULTS AND DISCUSSION}

DNA similarities. The DNA similarity results for the Pseudomonas species representing each rRNA similarity cluster are shown in Tables 1 through 4 . There are examples where there are high levels of DNA similarity between species, which are discussed below, but most of the species within each rRNA cluster have interspecies similarity values in the 5 to $20 \%$ range. Although the similarity values are low, reciprocal values (Table 1 ) are very close, so that we believe that most of the values that differ by $5 \%$ are significant. In addition, there appears to be a good correlation between these small DNA similarity differences and the rRNA similarity results (3). The average DNA similarity values between species belonging to different rRNA similarity clusters are very low (not more than 1 to $2 \%$ ) (Table 5). 
TABLE 1. Levels of DNA similarity among rRNA similarity group I species

\begin{tabular}{|c|c|c|c|c|c|c|c|c|c|c|c|}
\hline \multirow{2}{*}{$\begin{array}{c}\text { Source of } \\
\text { unlabeled DNA }\end{array}$} & \multicolumn{11}{|c|}{ \% Similarity with labeled DNA from strain: } \\
\hline & $\begin{array}{l}\text { ATCC } \\
15692\end{array}$ & $\begin{array}{l}\text { ATCC } \\
14909^{\mathrm{T} a}\end{array}$ & $\begin{array}{l}\text { ATCC } \\
25411^{\mathrm{T}}\end{array}$ & $\begin{array}{l}\text { ATCC } \\
17591^{\mathrm{T}}\end{array}$ & $\begin{array}{l}\text { ATCC } \\
25941^{\mathrm{T}}\end{array}$ & $\begin{array}{l}\text { ATCC } \\
9890^{1}\end{array}$ & $\begin{array}{l}\text { ATCC } \\
13525^{\mathrm{T}}\end{array}$ & $\begin{array}{l}\text { ATCC } \\
9447\end{array}$ & $\begin{array}{l}\text { ATCC } \\
12633^{T}\end{array}$ & $\begin{array}{l}\text { ATCC } \\
13453\end{array}$ & $\begin{array}{l}\text { ATCC } \\
10857^{\mathrm{T}}\end{array}$ \\
\hline P. aeruginosa ATCC $15692^{b}$ & (100) & & 19 & & 15 & & & 18 & 6 & 9 & \\
\hline$P$. alcaligenes ATCC $14909^{\mathrm{T}}$ & 15 & $(100)$ & 23 & 14 & 12 & 10 & 9 & 14 & 14 & 8 & 8 \\
\hline P. mendocina ATCC $25411^{\mathrm{T}}$ & 13 & 23 & $(100)$ & 14 & 10 & 9 & 8 & 12 & 11 & 6 & 8 \\
\hline P. stutzeri ATCC $17591^{\mathrm{T}}$ & 10 & 15 & 13 & $(100)$ & 7 & 6 & 6 & 8 & 9 & 4 & 6 \\
\hline$P$. agarici ATCC $25941^{\mathrm{T}}$ & 9 & 10 & 10 & 6 & $(100)$ & 16 & 16 & 20 & 13 & 10 & 12 \\
\hline$P$. agarici ATCC 25943 & 9 & 10 & 10 & 7 & 100 & 16 & 16 & 20 & 14 & 10 & 11 \\
\hline$P$ svnxantha ATCC $9890^{\mathrm{T}}$ & 10 & 11 & 12 & 7 & 21 & $(100)$ & 43 & 25 & 17 & 12 & 13 \\
\hline P. fluorescens ATCC $13525^{\mathrm{T}}$ & 10 & 11 & 11 & 7 & 21 & 44 & $(100)$ & 27 & 16 & 12 & 14 \\
\hline P. chlororaphis ATCC $9447^{\circ}$ & 16 & 16 & 16 & 11 & 27 & 29 & 28 & $(100)$ & 22 & 15 & 18 \\
\hline P. aureofaciens ATCC 13986 & 17 & 16 & 15 & 10 & 27 & 28 & 26 & 81 & 21 & 15 & 18 \\
\hline$P$. putida ATCC $12633^{\mathrm{T}}$ & 11 & 14 & 13 & 9 & 15 & 15 & 15 & 19 & $(100)$ & 11 & 13 \\
\hline P. fragi ATCC $4973^{\mathrm{T}}$ & 8 & $\begin{array}{r}14 \\
9\end{array}$ & 8 & 8 & 15 & 17 & 16 & 17 & 13 & 9 & 11 \\
\hline$P$. angulata ATCC 13453 & 7 & 9 & 10 & 8 & 14 & 14 & 13 & 15 & 12 & $(100)$ & 25 \\
\hline P. syringae ATCC $19304^{d}$ & 6 & 8 & 10 & 7 & 15 & 13 & 18 & 18 & 12 & 76 & 23 \\
\hline P. syringae ATCC $19875^{\circ}$ & 8 & 9 & 9 & 7 & 21 & 14 & 13 & 16 & 12 & 53 & 24 \\
\hline P. cichorii ATCC $10857^{\mathrm{T}}$ & 8 & 9 & 10 & 7 & 15 & 14 & 13 & 15 & 13 & 21 & $(100)$ \\
\hline
\end{tabular}

${ }^{a} \mathrm{~T}=$ type strain.

${ }^{b}$ Strain ATCC $10145^{\mathrm{T}}$ exhibits $78 \%$ similarity with strain ATCC 15692.

c Strain ATCC $9446^{\mathbf{T}}$ exhibits $100 \%$ similarity with strain ATCC 9447.

${ }^{d} P$. syringae pv. phaseolicola.

e $P$. syringae pv. panici.

Our S1 nuclease similarity results differ from the previous membrane competition results $(1,25,29)$ by being about 15 to $20 \%$ lower. This is due to the digestion by S1 nuclease of short noncomplementary regions that were included by the membrane competition measurements (1).

The dendrogram shown in Fig. 1 summarizes the results of our DNA similarity experiments on members of rRNA similarity group I. By taking into consideration DNA similarity values above $50 \%$, single branches are drawn for the three clusters constituted by (i) the two strains of the mushroom pathogen Pseudomonas agarici, (ii) the strains of Pseudomonas chlororaphis and Pseudomonas aureofaciens, and (iii) the strains of the nomenspecies Pseudomonas syringae, $P$. angulata, and $P$. panici.

In our interspecies comparisons, the highest similarity values for group I organisms were obtained between the strains of $P$. chlororaphis and $P$. aureofaciens. This finding is in agreement with previous results (25) and casts new doubts on the convenience of maintaining these two taxa under different species names. Consequently, a formal recommendation for assignment of all strains of the two groups to a single species is included below. Our use of strain ATCC 9447 of $P$. chlororaphis instead of the type strain, strain ATCC 9446, seems justified, since these two strains share $100 \%$ DNA sequence similarity (Table 1 ).

TABLE 2. Levels of DNA similarity among rRNA similarity group II species

\begin{tabular}{|c|c|c|c|c|}
\hline \multirow{2}{*}{$\begin{array}{c}\text { Source of } \\
\text { unlabeled DNA }\end{array}$} & \multicolumn{4}{|c|}{$\begin{array}{l}\text { \% Similarity with labeled DNA } \\
\text { from strain: }\end{array}$} \\
\hline & $\begin{array}{l}\text { ATCC } \\
25416^{\mathrm{T}}\end{array}$ & $\begin{array}{l}\text { ATCC } \\
10248^{\mathrm{T}}\end{array}$ & $\begin{array}{l}\text { ATCC } \\
23060\end{array}$ & $\begin{array}{l}\text { ATCC } \\
17697^{1}\end{array}$ \\
\hline P. cepacia ATCC $25416^{\mathrm{T}}$ & $(100)$ & 7 & 3 & 8 \\
\hline P. pyrrocinia ATCC $15958^{\mathrm{T}}$ & 15 & 12 & 13 & 6 \\
\hline P. gladioli ATCC $10248^{\mathrm{T}}$ & & $(100)$ & 4 & 8 \\
\hline P. gladioli ATCC 24517 & 2 & 98 & 4 & 8 \\
\hline P. andropogonis ATCC 23060 & 3 & 1 & $(100)$ & 2 \\
\hline P. solanacearum ATCC 10692 & 6 & 0 & 1 & 11 \\
\hline A. eutrophus ATCC $17697^{\mathrm{T}}$ & 7 & 5 & 2 & (100) \\
\hline
\end{tabular}

Aside from the $P$. chlororaphis- $P$. aureofaciens relationship, the highest level of similarity in Fig. 1 is represented by the species $P$. synxantha and Pseudomonas fluorescens. These two species are phenotypically similar, as shown by Jessen (14), who found that strains of both species are positive for gelatin liquefaction, denitrification, growth at low temperature $\left(4\right.$ to $\left.5^{\circ} \mathrm{C}\right)$, utilization of galactose for growth, and acid formation from trehalose. All of these characteristics are typically positive for $P$. fluorescens biotypes (35). $P$. synxantha and $P$. fluorescens join the $P$. chlororaphis- $P$. aureofaciens cluster in Fig. 1 at a substantial level of DNA similarity, which is not surprising because these two taxa were previously included among the biotypes of $P$. fluorescens (35).

The high level of similarity between the $P$. angulata strain and $P$. syringae (Table 1 ) supports the lumping of these two taxa under a single species name, $P$. syringae (see below). These two taxa are integrated here into the $P$. syringae branch of the dendrogram (Fig. 1). Jessen (14) examined strains NCPPB 79, NCPPB 214, and NCPPB 263 of $P$. angulata and assigned them to three different biotypes (biotypes 63, 69, and 70) in his system of classification. One strain under the same label was studied by Sands et al. (30) and was placed in a group with $P$. syringae; however, later, Pecknold and Grogan (28) placed their four strains (named Pseudomonas tabaci, a synonym of $P$. angulata) in their "morsprunorum" group, which was separated from the "syringae" group of these authors.

Another phytopathogenic species, Pseudomonas cichorii, joins the $P$. syringae branch in Fig. 1 at a $23 \%$ similarity level, which is consistent with the fact that this species is separated from the rest of the fluorescent plant pathogens by virtue of a positive oxidase reaction (24). Low similarity values between $P$. cichorii and other Pseudomonas species have been reported previously $(25,28)$.

Finally, the dendrogram in Fig. 1 shows the rather isolated position of Pseudomonas aeruginosa. As mentioned elsewhere $(21,35)$, this species is very sharply defined on phenotypic grounds and by DNA base composition. Its isolation is also emphasized in tridimensional representa- 
TABLE 3. Levels of DNA similarity among rRNA similarity group II species

\begin{tabular}{|c|c|c|c|c|c|c|c|}
\hline \multirow{2}{*}{$\begin{array}{c}\text { Source of } \\
\text { unlabeled DNA }\end{array}$} & \multicolumn{7}{|c|}{ \% Similarity with labeled DNA from strain: } \\
\hline & ATCC $15946^{\mathrm{T}}$ & ATCC $17724^{\mathrm{T}}$ & ATCC 17506 & ATCC $19860^{\top}$ & ATCC $15668^{\mathrm{T}}$ & ATCC $17713^{\mathrm{T}}$ & ATCC $11996^{\mathrm{T}}$ \\
\hline P. saccharophila ATCC $15946^{\mathrm{T}}$ & $(100)$ & 9 & 6 & 6 & 6 & 7 & 3 \\
\hline P. palleronii ATCC $17724^{\mathrm{T}}$ & 6 & $(100)$ & 11 & 10 & 7 & 10 & 6 \\
\hline P. delafieldii ATCC 17506 & 6 & 12 & $(100)$ & 15 & 13 & 10 & 4 \\
\hline P. delafieldii ATCC $17505^{\mathrm{T}}$ & 6 & 12 & 83 & 15 & 11 & 10 & 4 \\
\hline P. facilis ATCC $11228^{\mathrm{T}}$ & 10 & 12 & 49 & 15 & 10 & 10 & 8 \\
\hline P. avenae ATCC $19860^{\mathrm{T}}$ & 7 & 12 & 16 & $(100)$ & 13 & 12 & 12 \\
\hline P. acidovorans ATCC $15668^{\mathrm{T}}$ & 6 & 13 & 15 & 16 & $(100)$ & 10 & 12 \\
\hline P. acidovorans ATCC 17476 & 6 & 15 & 15 & 17 & 80 & 10 & 9 \\
\hline A. paradoxus ATCC $17713^{\mathrm{T}}$ & 7 & 15 & 13 & 16 & 10 & $(100)$ & 6 \\
\hline P. testosteroni ATCC $11996^{\mathrm{T}}$ & & & & & & & $(100)$ \\
\hline P. testosteroni ATCC 17510 & 5 & 9 & 10 & 10 & 16 & 6 & 77 \\
\hline
\end{tabular}

tions of similarity data (D. C. Hildebrand and N. J. Palleroni, unpublished data). For our experiments we used strain ATCC 15692, and not the type strain (strain ATCC 10145). However, these two strains have a very high DNA similarity level (Table 1).

As expected, the nonfluorescent members of the group (Pseudomonas alcaligenes, Pseudomonas mendocina, Pseudomonas stutzeri, and $P$. fragi) are only marginally related to the fluorescent species.

The data obtained in DNA hybridization experiments performed with members of Pseudomonas rRNA similarity group II are shown in Table 2 . The strain of $P$. andropogonis (synonym, Pseudomonas stizolobii), a plant-pathogenic species, has a very low level of similarity with other species of the group. The strain used in our experiments (strain ATCC 23060) is not the type strain (strain ATCC 23061), but these two strains are very similar phenotypically and were assigned to the same pathovar $(P$. andropogonis pv. andropogonis), since both are pathogenic for species of the Gramineae. $P$. andropogonis was tentatively classified in group III by Byng et al. (4). This organism was later clearly shown to belong to rRNA similarity group II, but groups II and III are the most closely related of the rRNA clusters (3). The organism is peculiar in a number of properties (A. C. Hayward, personal communication), including the fact that the cells have a sheathed flagellum. Perhaps $P$. andropogonis should be placed in an intermediate position between groups II and III.

A substantial level of DNA similarity has been demonstrated between some Pseudomonas cepacia strains and $P$. pyrrocinia (data not shown), but there is only a modest relationship between the latter species and the type strain of $P$. cepacia (Table 2). As shown by Elander et al. (8), pyrrolnitrin, the antibiotic characteristic of $P$. pyrrocinia, can also be produced by strains of $P$. cepacia. On the other hand, the strains of $P$. cepacia show a marked heterogeneity in DNA sequence similarity (1). Therefore, it would be worthwhile to subject $P$. pyrrocinia strains in the future to a detailed phenotypic analysis to define other points of similarity between the two species.

A. eutrophus and the other group II species exhibit high levels of similarity in their rRNA sequences (3) and are also linked by low levels of DNA similarity (Table 2). Phenotypically, A. eutrophus resembles the members of group III, particularly Pseudomonas acidovorans (D. H. Davis, Ph.D. thesis, University of California, Berkeley, 1967), again reflecting the higher levels of rRNA relatedness between group II and III organisms.

Only one strain of Pseudomonas solanacearum, which was not the type strain, was examined in our study. This species is quite complex, and DNA hybridization experiments have shown various degrees of sequence similarity (26); these findings indicate the limited value of our resuls for this species and the need to include more strains in future studies.

One small cluster can be recognized in Table 3 , represented by the hydrogen pseudomonad Pseudomonas facilis and its obligate heterotrophic counterpart, Pseudomonas delafieldii. These two species are almost identical in phenotype. The differences between them are in the capacity for utilization of a few substrates, in gelatin liquefaction $(P$. facilis has a stronger activity than $P$. delafieldii), and in the capacity for living autotrophically in contact with an atmosphere containing hydrogen, oxygen, and carbon dioxide. In a previous study (29) the two species were found to be indistinguishable by DNA reannealing experiments, but in our study, this total DNA identity was not evident, although the level of similarity was relatively high $(49 \%)$.

TABLE 4. Levels of DNA similarity among rRNA similarity group V species

\begin{tabular}{|c|c|c|c|c|c|c|}
\hline \multirow{2}{*}{$\begin{array}{c}\text { Source of } \\
\text { unlabeled DNA }\end{array}$} & \multicolumn{6}{|c|}{ \% Similarity with labeled DNA from strain: } \\
\hline & ATCC 17806 & ATCC $13637^{\mathrm{T}}$ & ATCC 19867 & ATCC $33913^{\mathbf{T}}$ & ATCC 19865 & ATCC 8721 \\
\hline X. maltophilia ATCC 17806 & (100) & 48 & 54 & 16 & 3 & 13 \\
\hline$X$. maltophilia ATCC $13637^{\mathrm{T}}$ & 52 & $(100)$ & 71 & 2 & 1 & 11 \\
\hline X. maltophilia ATCC 19867 & 50 & 62 & $(100)$ & 13 & 5 & 13 \\
\hline P. geniculata (X. maltophilia) ATCC 19374 & 53 & 64 & 71 & 14 & 4 & 13 \\
\hline X. campestris ATCC $33913^{\mathrm{T}}$ & & & & $(100)$ & 22 & \\
\hline X. campestris ATCC 19865 & 15 & 13 & 16 & 33 & $(100)$ & 77 \\
\hline X. campestris pv. pelargonii АTCC 8721 & 16 & 13 & 15 & 14 & 64 & (100) \\
\hline X. campestris pv. phaseoli ATCC 9563 & 16 & 13 & 17 & 25 & 22 & 45 \\
\hline X. campestris pv. malvacearum ATCC 9924 & 14 & 13 & 16 & 16 & 20 & 43 \\
\hline
\end{tabular}


TABLE 5. Levels of intergroup DNA similarity among rRNA similarity groups

\begin{tabular}{ccccc}
\hline \multirow{2}{*}{$\begin{array}{c}\text { rRNA } \\
\text { similarity group }\end{array}$} & \multicolumn{4}{c}{ Similarity with rRNA } \\
\cline { 2 - 5 } & I & V & II & III \\
\hline I & & 2.1 & 2.0 & 2.0 \\
V & 1.0 & & 0.9 & 2.1 \\
II & 2.0 & 1.8 & & 3.2 \\
III & 1.5 & 2.0 & 2.1 & \\
IV & 1.4 & & 1.0 & 2.7 \\
\hline
\end{tabular}

The data in Table 3 clearly show that, despite the fact that rRNA similarity group III includes all of the hydrogen pseudomonads, the three species which we studied (Pseudomonas saccharophila, Pseudomonas facilis, and Pseudomonas palleronii) exhibit relatively low levels of DNA similarity, supporting the concept of the limited taxonomic value of hydrogen utilization at the species level (6; Davis, Ph.D. thesis).

In the same group III (Table 3), P. acidovorans and Pseudomonas testosteroni appear to be related at only a low level as determined by DNA similarity experiments, as expected. Our values are in agreement with the low values reported previously (25). The two species have marked phenotypic similarities (35), but their DNA base compositions differ by $5 \mathrm{~mol} \%$ (21).

Table 4 summarizes the hybridization data for members of rRNA group $\mathrm{V}$. The group $\mathrm{V}$ strains are divided into two subgroups; one subgroup contains Xanthomonas campestris strains, and the other contains Xanthomonas maltophilia and $P$. geniculata. There is substantial heterogeneity among the strains in each subgroup. Heterogeneity among $X$. maltophilia strains has also been observed by Ikemoto and collaborators (13), who delineated five clusters, all having intercluster similarity values similar to those shown in Table 4.

Strains of different Pseudomonas species within each of the rRNA groups share substantial degrees of rRNA similarity $(3,27)$, while most of the DNA sequences seem to have undergone considerable divergence, as judged by the low levels of DNA similarity obtained in hybridization experiments (25; this paper). In contrast, strains of different

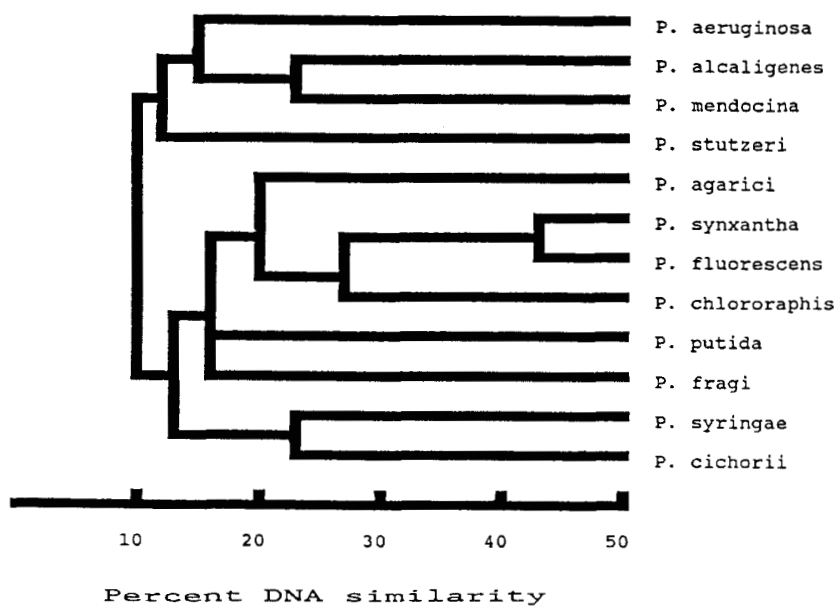

FIG. 1. Dendrogram of DNA similarity values for rRNA similarity group I species. The cluster analysis of the average DNA similarity values was calculated from Table 1 by using the unweighted pair group method. species of other genera may show in their DNAs a degree of conservatism approaching that of the ribosomal genes (18). It is tempting to attribute these peculiar properties of the pseudomonads to the ubiquitous occurrence of these organisms and the concomitant need for adjustment to the selective pressures of highly variable natural habitats (17).

Nomenclatural considerations. (i) Comments on some of the strains used in the nucleic acid hybridization experiments. The names of some of the strains used in this and previous work (3) deserve comments, since they are either synonymous with other names or have been changed in current taxonomic treatments of the genus.

One of the two P. synxantha strains studied by Jessen (14) was included in this study. The second strain was examined for its phenotypic properties by us and was found to belong to biotype $\mathrm{G}$ (biovar $\mathrm{V}$ ) of $P$. fluorescens (data not shown).

The species name $P$. angulata is a synonym of $P$. tabaci, which has priority over $P$. angulata, but at present it designates a pathovar of $P$. syringae. Consequently, the accepted name is $P$. syringae pv. tabaci $(7,24)$.

There is considerable confusion in the literature and in collection catalogs concerning the specific epithets panici and panacis. Recently, a recommendation has been made for the rejection of the epithet panici, which was not meant to be applied to fluorescent organisms (11); however, the strain included in our studies, as well as in the studies of other workers $(3,7,28,30)$, is definitely a pathovar of $P$. syringae, although its origin is unclear.

$P$. geniculata ( $P$. maltophilia ATCC 19374) was included in our study for the first time in DNA hybridization experiments, and until its recent assignment to group $\mathrm{V}$ (3), its taxonomic position appeared to be uncertain (24). That the uncertainty still continues will perhaps be clear after the discussion below. $P$. geniculata was described by Haynes and Burkholder in Bergey's Manual of Determinative Bacteriology, 7th ed. (10), among the fluorescent pseudomonads. According to the original description (5), the strains of this organism produce a green color in some media, but fluorescence is not specifically mentioned. The colonies are yellowish, and under certain conditions a diffusible brown pigment may be produced. The type strain of $P$. geniculata has not survived, and it is clear from a search of the literature that the description of the colors has been interpreted differently by later authors. Thus, three strains of the species were examined by Stanier et al. (35), who found them to be typical fluorescent pseudomonads and to correspond to $P$. fluorescens biotype G. On the other hand, one strain studied by Lysenko (20) produced no fluorescent pigment but had yellowish colonies and produced a diffusible brown pigment. Recently, this strain was examined by Byng et al. (3) for its rRNA composition and was assigned to rRNA group V. In all of the papers by this group of workers this organism is included under the name $P$. geniculata. This strain is listed in the American Type Culture Collection Catalog, 15th ed. (American Type Culture Collection, Rockville, Md.), among the strains of $P$. maltophilia, a species with which the strain shares the same colony color and brown diffusible pigment (24). Our DNA hybridization data confirm this diagnosis, but whether the original $P$. geniculata type was a green fluorescent pseudomonad or a representative of one of the $P$. maltophilia similarity clusters remains an unanswered question.

It has been recommended (12) that the name Pseudomonas marginata should be changed to Pseudomonas gladioli.

Likewise, Pseudomonas alboprecipitans has been invalidated in favor of Pseudomonas avenae (31). 
(ii) Proposal of synonymy of $\boldsymbol{P}$. chlororaphis (Guignard and Sauvageau 1894) Bergey, Harrison, Breed, Hammer and Huntoon 1930, 166, and $P$. aureofaciens Kluyver 1956, 406. Strains of $P$. chlororaphis (Guignard and Sauvageau 1894) Bergey, Harrison, Breed, Hammer, and Huntoon 1930 (2) and $P$. aureofaciens Kluyver 1956 (19) were examined by Stanier et al. (35) and were assigned to biotypes D and E of $P$. fluorescens, a species which they resemble in the production of fluorescent pigment and in gelatin liquefaction. $P$. chlororaphis and $P$. aureofaciens are identical to one another in many nutritional properties. Thus, the only absolute differences (i.e., properties found in all of the strains of one species and in none of the strains of the other) are the use of $\mathrm{L}$-arabinose, D-alanine, and $\alpha$-amylamine (24). However, a recent repetition of the nutritional tests has given discrepant results for $\mathrm{D}$-alanine and $\alpha$-amylamine; both species are positive for utilization of $D$-alanine, and the use of $\alpha$ amylamine is not universal among $P$. chlororaphis strains.

Strains of both species produce levan from sucrose. Strains named $P$. chlororaphis produce the green phenazine pigment chlororaphin, while $P$. aureofaciens cultures produce the orange pigment phenazine monocarboxylate, which is closely related to chlororaphin (34). Only one of the species ( $\boldsymbol{P}$. chlororaphis) is capable of denitrification.

The strong similarities between the two species were further supported by their identical DNA base compositions (ca. 63.5 mol\% guanine plus cytosine) (21) and a high level of DNA similarity (25; this paper). At the time that the last treatment of the genus Pseudomonas was written (24), the facts described above suggested the convenience of restoring the two biotypes to their former species status.

It is our opinion that the level of DNA similarity shared by the strains is sufficiently high to justify lumping the two species into one taxon, for which the name $P$. chlororaphis should be used based on priority.

Properties of interest for the differentiation of $P$. chlororaphis from most $P$. fluorescens biotypes are the capacity for formation of certain phenazine pigments (phenazine monocarboxylate or its amide, chlororaphin) (34), the utilization of benzoyl formate, and the inability to grow with D-xylose, L-rhamnose, citraconate, and sorbitol. Many additional phenotypic properties are listed in Bergey's Manual of Systematic Bacteriology, vol. 1 (24).

\section{LITERATURE CITED}

1. Ballard, R. W., N. J. Palleroni, M. Doudoroff, R. Y. Stanier, and M. Mandel. 1970. Taxonomy of the aerobic pseudomonads: Pseudomonas cepacia, $P$. marginata, $P$. aliicola, and $P$. caryophylli. J. Gen. Microbiol. 60:199-214.

2. Bergey, D. H., F. C. Harrison, R. S. Breed, B. W. Hammer, and F. M. Huntoon. 1930. Bergey's manual of determinative bacteriology, 3rd ed. The Williams \& Wilkins Co., Baltimore.

3. Byng, G. S., J. L. Johnson, R. J. Whitaker, R. L. Gherna, and R. A. Jensen. 1983. The evolutionary pattern of aromatic amino acid biosynthesis and the emerging phylogeny of pseudomonad bacteria. J. Mol. Evol. 19:272-282.

4. Byng, G. S., R. J. Whitaker, R. L. Gherna, and R. A. Jensen. 1980. Variable enzymological patterning in tyrosine biosynthesis as a means of determining natural relatedness among the Pseudomonadaceae. J. Bacteriol. 144:247-257.

5. Chester, F. D. 1901. A manual of determinative bacteriology. The Macmillan Co., New York.

6. Davis, D. H., M. Doudoroff, R. Y. Stanier, and M. Mandel. 1969. Proposal to reject the genus Hydrogenomonas: taxonomic implications. Int. J. Syst. Bacteriol. 19:375-390.

7. Dye, D. W., J. F. Bradbury, R. S. Dickey, M. S. Goto, C. N. Hale, A. C. Hayward, A. Kelman, R. A. Lelliott, P. N. Patell, D. C. Sands, M. N. Schroth, D. R. W. Watson, and J. M. Young.
1975. Proposal for a reappraisal of the status of names of plant-pathogenic Pseudomonas species. Int. J. Syst. Bacteriol. 25:252-257.

8. Elander, R. P., J. A. Mabe, R. H. Hamill, and M. Gorman. 1968. Metabolism of tryptophans by Pseudomonas aureofaciens. VI. Production of pyrrolnitrin by selected Pseudomonas species. Appl. Microbiol. 16:753-758.

9. Guignard, L., and C. Sauvageau. 1894. Sur un noveau microbe chromogène le Bacillus chlororaphis. C. R. Soc. Biol. Paris Ser. $10,1: 841-843$.

10. Haynes, W. C., and W. H. Burkholder. 1957. Genus I. Pseudomonas Migula 1894, p. 89-152. In R. S. Breed, E. G. D. Murray, and N. R. Smith (ed.), Bergey's manual of determinative bacteriology, 7th ed. The Williams \& Wilkins Co., Baltimore.

11. Hildebrand, D. C., and N. J. Palleroni. 1987. Misidentification of Pseudomonas strain NCPPB 1498 (ATCC 19875) and proposal for a rejection of the name Pseudomonas syringae pv. panici (Elliott 1923) Young et al. 1978. Lett. Appl. Microbiol. 5:27-28.

12. Hildebrand, D. C., N. J. Palleroni, and M. Doudoroff. 1973. Synonymy of Pseudomonas gladioli Severini 1913 and Pseudomonas marginata (McCulloch 1921) Stapp 1928. Int. J. Syst. Bacteriol. 23:433-437.

13. Ikemoto, S., K. Suzuki, T. Kaneko, and K. Komagata. 1980. Characterization of strains of Pseudomonas maltophilia which do not require methionine. Int. J. Syst. Bacteriol. 30:437-447.

14. Jessen, O. 1965. Pseudomonas aeruginosa and other green fluorescent pseudomonads. A taxonomic study. Munksgaard, Copenhagen.

15. Johnson, J. L. 1981. Genetic characterization, p. 450-472. In P. Gerhardt, R. G. E. Murray, R. N. Costilow, E. W. Nester, W. A. Wood, N. R. Krieg, and G. B. Phillips (ed.), Manual of methods for general microbiology. American Society for Microbiology, Washington, D.C.

16. Johnson, J. L., and B. S. Francis. 1975. Taxonomy of the clostridia: ribosomal ribonucleic acid homologies among the species. J. Gen. Microbiol. 88:229-244.

17. Johnson, J. L., and B. Harich. 1983. Comparison of procedures for determining ribosomal ribonucleic acid similarities. Curr. Microbiol. 9:111-120.

18. Johnson, J. L., and B. Harich. 1986. Ribosomal ribonucleic acid homology among species of the genus Bacteroides. Int. J. Syst. Bacteriol. 36:71-79.

19. Kluyver, A. J. 1956. Pseudomonas aure'ofaciens nov. spec. and its pigments. J. Bacteriol. 72:406-411.

20. Lysenko, O. 1961. Pseudomonas - an attempt at a general classification. J. Gen. Microbiol. 25:379-408.

21. Mandel, M. 1966. Deoxyribonucleic acid base composition in the genus Pseudomonas. J. Gen. Microbiol. 43:273-292.

22. Marmur, J. 1961. A procedure for the isolation of deoxyribonucleic acid from microorganisms. J. Mol. Biol. 3:208-218.

23. Palleroni, N. J. 1983. The taxonomy of bacteria. BioScience 33:370-377.

24. Palleroni, N. J. 1984. Genus I. Pseudomonas Migula 1894, p. 141-199. In N. R. Krieg and J. G. Holt (ed.), Bergey's manual of systematic bacteriology, vol. 1. The Williams \& Wilkins Co., Baltimore.

25. Palleroni, N. J., R. W. Ballard, E. Ralston, and M. Doudoroff. 1972. Deoxyribonucleic acid homologies among some Pseudomonas species. J. Bacteriol. 110:1-11.

26. Palleroni, N. J., and M. Doudoroff. 1971. Phenotypic characterization and deoxyribonucleic acid homologies of Pseudomonas solanacearum. J. Bacteriol. 107:690-696.

27. Palleroni, N. J., R. Kunisawa, R. Contopoulou, and M. Doudoroff. 1973. Nucleic acid homologies in the genus Pseudomonas. Int. J. Syst. Bacteriol. 23:333-339.

28. Pecknold, P. C., and R. G. Grogan. 1973. Deoxyribonucleic acid homology groups among phytopathogenic Pseudomonas species. Int. J. Syst. Bacteriol. 23:111-121.

29. Ralston, E., N. J. Palleroni, and M. Doudoroff. 1972. Deoxyribonucleic acid homologies of some so-called "Hydrogenomonas" species. J. Bacteriol. 109:465-466. 
30. Sands, D. C., M. N. Schroth, and D. C. Hildebrand. 1970. Taxonomy of phytopathogenic pseudomonads. J. Bacteriol. 101:9-23.

31. Schaad, N. W., C. I. Kado, and D. R. Sumner. 1975. Synonymy of Pseudomonas avenae Manns 1905 and Pseudomonas alboprecipitans Rosen 1922. Int. J. Syst. Bacteriol. 25:133-137.

32. Selin, Y. M., B. Harich, and J. L. Johnson. 1983. Preparation of labeled nucleic acids (nick translation and iodination) for DNA homology and rRNA hybridization experiments. Curr. Microbiol. 8:127-132.
33. Skerman, V. B. D., V. McGowan, and P. H. A. Sneath (ed.). 1980. Approved lists of bacterial names. Int. J. Syst. Bacteriol. 30:225-420.

34. Sneath, P. H. A. 1961. A study of the genus Chromobacterium. Iowa State J. Sci. 34:243-500.

35. Stanier, R. Y., N. J. Palleroni, and M. Doudoroff. 1966. The aerobic pseudomonads: a taxonomic study. J. Gen. Microbiol. 43:159-271.

36. Tereba, A., and B. J. McCarthy. 1973. Hybridization of ${ }^{125} \mathrm{I}$ labeled ribonucleic acid. Biochemistry 12:4675-4679. 